ELORE (ISSN 1456-3010), vol. $13-1 / 2006$.

Julkaisija: Suomen Kansantietouden Tutkijain Seura ry. Taitto: Jukka Talve.

[http://cc.joensuu.fi/ /oristi/1_06/kur1_06.pdf]

\title{
Ajankohtaista:
}

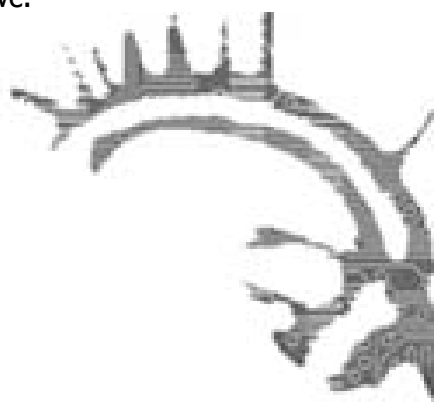

\section{KARJALA-TUTKIJAT LIIKKEELLÄ JOENSUUSSA}

Liikekeellä. SKS:n jublaseminaari 12.-14.1.2006, Joensun

Tuulikki Kurki

Joensuun yliopiston perinteentutkimuksen oppiaine, Suomalaisen Kirjallisuuden Seura ja SKS:n Joensuun perinnearkisto järjestivät Liikkeellä-seminaarin SKS:n 175vuotisjuhlavuoden kunniaksi. Seminaari pidettiin 12.-14. tammikuuta Joensuun yliopistossa, ja sen tavoitteena oli virittää keskustelua Karjala-tutkimuksen nykynäkymistä ja tulevaisuudesta.

Seminaarin aloitti Suomalaisen Kirjallisuuden Seuran jäsenilta, jossa kielentutkija Jaakko Yli-Paavola esitelmöi Pertti Virtarannan kenttämatkoista Karjalan alueella. Ensimmäiset matkansa alueelle Virtaranta teki jo 1950-luvun lopulla. Useiden vuosikymmenien aikana hän keräsi muiden muassa satoja tunteja käsittävän ääninauhakokoelman karjalan murteista. Illan päätti Maari Kallbergin (SibeliusAkatemia) vaikuttava esitys, jossa hän tulkitsi musiikintutkija A. O. Väisäsen 1900luvun alun kenttäpäiväkirjojen pohjalta runoja ja itkuvirsiä. Illassa oli viitisenkymmentä kuulijaa.

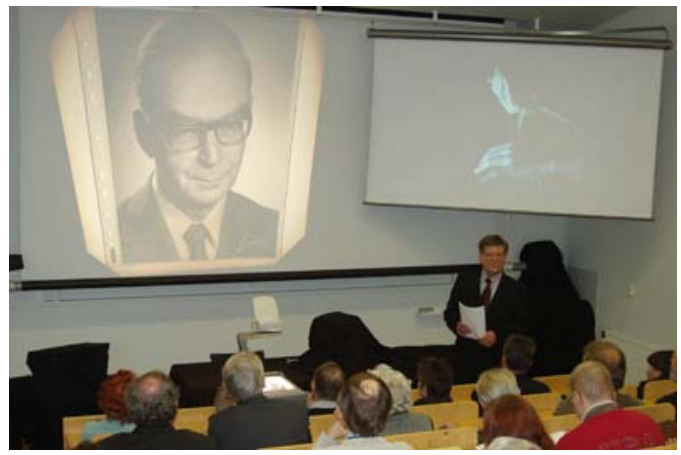

Jaakeko Yli-Paavola luennoi Pertti Virtarannasta. Kuvaaja: Tellervo Hirvonen. 


\section{KarJalaisuUs, KIELI Ja PERINNE}

Kahden seuraavan päivän osuudet kokosivat joukon Karjalan aluetta käsitteleviä tutkijoita Petroskoista, Helsingistä ja Joensuusta sekä monikymmenisen joukon kiinnostunutta yleisöä. Perjantaipäivän teemana oli "Karjalaisuus, kieli ja perinne". Päivän alustukset kartoittivat aihetta Kalevalan, kansanomaisen paikannimistön, itkuperinteen ja transnationaalisten identiteettiprosessien näkökulmista.

Petroskoilainen kirjallisuudentutkija ja kääntäjä Eino Kiuru kertoi Armas Mišinin kanssa tekemästään Kalevalan uudesta venäjännöksestä ja sen tekoprosessista. Teoksessa on esitetty Lönnrotin teksti ja käännösteksti rinnakkain, mikä tekee siitä kiinnostavan poikkeuksellisen laajan lukijakunnan piirissä. Teos onkin saanut hyvän vastaanoton ja siitä on suunnitteilla jo neljäs painos. Sitä on myyty eniten Karjalan alueella, mutta jonkin verran myös Moskovassa ja Pietarissa. Kiuru ja Mišin ovat kääntäneet myös lyhennetyn Kalevalan laitoksen. Alku-Kalevalan käännös on puolestaan suunnitteilla julkaista vuonna 2006.

Kalevalan Lemminkäisen äiti ja kansanrunojen Neitsyt Moarie olivat Elina Rahimovan (HY) aiheena. Runoaiheet kuuluvat yleiseurooppalaiseen motiiviin, jossa kadonneen pojan tai veljen etsintä sekä äidin tai sisaren rooli etsijänä ovat juonikuvioiden keskeisiä ratkaisuja. Perinteentutkija Sandra Stepanova (Petroskoi) puolestaan luennoi karjalaisten itkujen tyylistä ja kielestä, joka rakentuu pitkälti metaforien ja kiertoilmaisujen varaan. Stepanova syventyi tarkemmin itkukielessä käytettyihin äidin ja lapsen metaforiin, joita onkin kymmeniä erilaisia. Stepanova on tehnyt kenttätyötä itkujen parissa vuodesta 1963 alkaen. Kenttätyöhön perustuen hän on koonnut 1350 sanaa sisältävän itkukielen sanakirjan, jota käännetään parhaillaan myös suomeksi.

Itkut olivat myös Eila Stepanovan (HY) aiheena. Hän luennoi nykyhetken yhden merkittävimmän itkijän Praskovja Saveljevan repertoaarista. Saveljevan repertoaarin laajin ryhmä ovat kuolinitkut, mutta siihen kuuluu myös arki-itkuja ja autobiografisia itkuja, joista saa käsityksen Saveljevan vaiherikkaasta elämänkulusta. Saveljeva joutui 1940-luvulla jatkosodan aikana Suomeen, ja tuona raskaana aikana lapsena omaksuttu itkutaito aktuaalistui. Saveljeva myöhemmätkin raskaat elämänvaiheet (mm. vakoiluepäily, raskas työ, lapsettomuus) ylläpitivät itkemistä. Saveljeva repertoaarista 1970-luvulta vuoteen 2002 saakka on koottu poikkeuksellisen laaja 92 itkun kokoelma.

Kielitieteilijä Olga Karlova (Petroskoin yliopisto) esitteli Vuokkiniemen alueen asukkaiden henkilönimiin ja henkilökohtaisiin ominaisuuksiin perustuvaa paikkanimistöä. Henkilönimiä on käytetty eniten talon- ja kylännimissä, mutta jonkin verran myös järvien ja jokien nimissä. Nimet säilyvät edelleen alueen asukkaiden puhekielessä, ne vaeltavat asukkaiden mukana ja niihin on liittyneenä runsaasti kansanomaisia etymologioita.

Olga Davydova Joensuun yliopistosta puhui Karjalan alueelta Suomeen tapahtuvasta emigraatiosta ja sen myötä rakentuvasta transnationaalisesta elämäntavasta ja identiteetistä. Sille on ominaista monipaikkaisuus, rajojen ylittäminen ja 
välillä oleminen. Davydova esitteli vuonna 2002 perustetun internet-keskustelufoorumin (ks. < www.suomi.ru $>$ ) yhtenä ylirajaisen ja monipaikkaisen identiteetin rakennuspaikkana, jossa kohtaavat sekä virtuaalinen että reaalinen yhteisö.

\section{UUDEMPAA NÄKÖKULMAA KARJALA-TUTKIMUKSEEN}

Seminaarin toisena päivänä kokoonnuttiin Karjala-tutkimuksen pyöreän pöydän äärelle. Alustajina olivat Tuulikki Kurki (JoY), Pekka Suutari (JoY), Jyrki Pöysä (JPA), Kaija Heikkinen (JoY), Outi Fingerroos (TY) ja Pekka Hakamies (JoY). Alustusten pohjalta keskusteltiin Karjalan alueen tutkimukseen liittyvistä, kenttätyön ja arkistotutkimuksen metodologisista ja lähdekritiikin kysymyksistä sekä Karjala-aiheisen kirjallisuuden julkaisemisesta ja kääntämisestä. Keskusteluissa korostui tutkijan tiedonintressin ja tutkijan "katseen" merkitys Karjala-kuvien rakentumisessa.

Seminaari toi kokonaisuudessaan esille sitä tutkimuksellisten kiinnostusten kirjoa, joka tällä hetkellä kohdistuu Karjalan alueeseen. Keskeisiksi teemoiksi nousivat Karjalaan kohdistuneen aiemman tutkimusperinteen "taakka", muuttuneet tiedonintressit ja tarve dokumentoida ja tutkia nykyajan ilmiöitä ja muutosprosesseja perinteisten kohteiden ohella. Alustusten pohjalta heräsikin kysymyksiä, miten perinteisiä, kanonisoituneita Karjala-kuvia voidaan rikkoa tai onko nykytutkimuksessa pyrkimyksiä niiden rikkomiseen? Näyttäytyykö tämän hetken tutkijoille Karjala ensisijaisesti alueena, joka kirjoitetaan olemassa olevaksi? Mitä Karjalatutkimuksen puitteissa voidaan tutkia ja mitä Karjala-tutkimus sisältää? Ainakin seminaarin alustusten ja keskustelujen perusteella kenttätyön ja arkistotutkimusten metodeissa sekä Karjalaan kohdistuvien erilaisten katseiden luonteessa on liikettä.

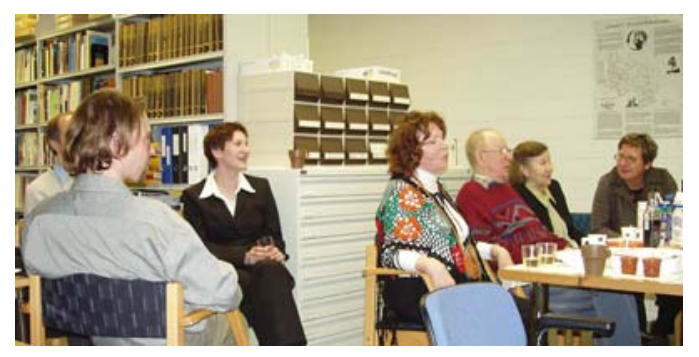

Seminaarin jälkeinen illanvietto Joensuun Perinnearkistolla. Kuvaaja: Jyrki Pöysä.

FT Tuulikki Kurki toimii tutkijatohtorina suomen kielen ja kulttuuritieteiden laitoksella Joensuun yliopistossa. 